\title{
Morphological Alterations of the Surfaces of Enamel and Dentin of Deciduous Teeth Irradiated with Nd:YAG, $\mathrm{CO}_{2}$ and Diode Lasers
}

\author{
Alteraciones Morfológicas de las Superficies de Esmalte y Dentina \\ de Dientes Deciduos Irradiados con Láseres de Nd:YAG, $\mathrm{CO}_{2}$ y Diodo
}

Mônica Rodrigues de Souza; Ii-Sei Watanabe; Luciane H. Azevedo \& Edgar Y. Tanji

SOUZA, M. R.; WATANABE, I.; AZEVEDO, L. H. \& TANJI, E. Y. Morphological alterations of the surfaces of enamel and dentin of deciduous teeth irradiated with Nd:YAG, $\mathrm{CO}_{2}$ and diode lasers. Int. J. Morphol., 27(2):441-446, 2009.

SUMMARY: In this work, we studied the effects of $\mathrm{CO}_{2}, \mathrm{Nd}: \mathrm{YAG}$ and diode lasers on the enamel and dentin of deciduous human teeth. After the irradiations, the samples were duly prepared and set up on metallic bases, covered with gold and examined in the scanning electron microscope. The results showed that the irradiation with the $\mathrm{CO}_{2}$ mode locked laser with $1.0 \mathrm{~W}$ power caused melting and irregularities with small cavities on the surface of the enamel. The irradiated area on the dentin surface appeared circular and well delimited, containing blocks of dentin and cracks. By using the pulsed Nd:YAG laser with $1.0 \mathrm{~W}$ mean power and $10 \mathrm{~Hz}$ frequency, the enamel surface presented granules of molten enamel, with a typical melting look. The irradiated dentin surface presented a cavity with a margin elevated with granules and holes, and its bottom presented dentinary tubules with globules of melted dentin. Irradiation with the mode locked of diode laser with $1.0 \mathrm{~W}$ mean power, showed the formation of a melted and evenly resolidified enamel surface, and the dentin surface presented a block of melted dentin with adjacent regions of normal dentin, evidently with a relatively smooth surface.

KEY WORDS: Deciduous tooth; Enamel; Dentin; $\mathrm{CO}_{2}$ laser; Nd:YAG laser; Diode laser; Scanning electron microscope.

\section{INTRODUCTION}

Several studies have shown the possible applications of different types of lasers in dentistry clinics, as for example, in the inhibition of carious lesions (Stern et al., 1966, 1972; Yamada, 1996), as well as in their removal (White et al., 1993), in the oral mucous (Taylor et al., 1965), and in gum healing (Chomette et al., 1987), among others. The scanning electron microscope has shown the different morphological alterations in the enamel and dentin surfaces irradiated with the $\mathrm{CO}_{2}$ laser (Takahashi et al., 1998; Watanabe et al., 1986), the diode laser (Wetter, 2002), and the Nd:YAG laser (Lin et al., 2001). However, most of these studies were carried out on permanent teeth. In deciduous teeth, the effects of the $\mathrm{CO}_{2}$, Nd:YAG and diode laser, were scarcely studied (Watanabe et al., 1990; Rode et al., 1994). Therefore, the objective of this work is to study the effects of the irradiation of these three kinds of lasers on the surface of enamel and dentin of deciduous human teeth with the scanning electron microscope.

\section{MATERIAL AND METHOD}

Thirty-two exfoliated human upper and lower deciduous teeth (incisor, canine, molar) were used, which were fractured with the help of a screw clamp lengthwise. To guide the fractures, orientation grooves were made with a high rotative diamond bur. The teeth were subsequently stored in 5\% sodium hypochlorite for 3 to 5 days, to remove the remaining soft tissue in the dental cavity. The teeth were then washed in distilled water, dehydrated in an increasing series of alcohol beginning with $60 \%$ up to the absolute, and left on filtered paper for 24 hours to dry. The samples were set up on a wooden base for the treatment with the lasers. Irradiation on the enamel surfaces were made on the buccal surface of the teeth, whereas irradiation on the dentin surfaces was made laterally to the pulpar cavity, always in a concentrated manner. After being irradiated, the samples were set up on metallic bases, covered with gold and examined on the JEOL 6100 scanning electron microscope. The parameters used were: $\mathrm{CO}_{2}$ laser: with $1.0 \mathrm{~W}$ power for 
6 seconds, and $84.9 \mathrm{~J} / \mathrm{cm}^{3}$ energy density in the locked method; Nd:YAG laser: $1.0 \mathrm{~W}$ mean power for 6 seconds, energy density of $84.9 \mathrm{~J} / \mathrm{cm}^{3}$ and frequency of $10 \mathrm{~Hz}$, in the pulsed method; diode laser: $1.0 \mathrm{~W}$ power for 6 seconds, 84.9 $\mathrm{J} / \mathrm{cm}^{3}$ energy density in the locked method. The $\mathrm{CO}_{2}$ Laser System apparatus, UM-L-30 model, of the Union Medical Engineering Co., the Nd:YAG Pulse Master apparatus, of the American Dental Technologies and the L808 diode laser model apparatus, were used at LELO-USP (Special Laboratory of Laser in Odontology in University of São Paulo).

\section{RESULTS}

The normal enamel surface of deciduous teeth presents characteristic depressions and enamel prisms (Fig. 1). The surface of the normal fractured dentin shows numerous parallel dentinary tubules (Fig. 2). Irregular areas with rugosities were formed on the surface of the enamel irradiated with $\mathrm{CO}_{2}$ laser. These can be noticed in their entire extension, with insertion of smooth enamel surfaces and presence of some cavities with variable sizes (Fig. 3). On the other hand, irradiation on the dentin surface showed the formation of a well-delimited circular surface, with blocks of fractured dentin and numerous fissures (Fig. 4).

The enamel surface irradiated with the Nd:YAG laser showed melting, with the presence of enamel granules and holes (Fig. 5). When the dentin surface was irradiated with the Nd:YAG laser, a very deep and delimited cavity was formed, with elevated margins (Fig. 6). The presence of granules and holes in the cavity margin became very evident due to the increased melting of the dentin surface (Fig. 7). In the bottom of the cavity, dentinary tubules, melted dentin globules and small holes and cracks were present (Fig. 8).

The aspect of fusion was noticed in some areas of the enamel surface irradiated with the diode laser (Fig. 9). On the other hand, the dentin surface revealed the delimitation of the region irradiated, forming a block of relatively smooth melted dentin, with adjacent regions of normal dentin (Fig. $10)$.

\section{DISCUSSION}

The results of this work revealed the effects of the action of 3 types of laser (the $\mathrm{CO}_{2}, \mathrm{Nd}$ :YAG and the diode) on the enamel and dentin surfaces of deciduous human teeth, through the scanning electron microscope. With regard to the $\mathrm{CO}_{2}$ laser action on the enamel surface of deciduous human teeth, our results showed the aspect of fusion and melting of the samples, similar to those related by McCormack et al. (1995) and Kantorowitz et al. (1996). Furthermore, we noticed the presence of extensive rugosities in all the area irradiated with laser, confirming the findings of Takahashi et al. Around the rugosities, we noticed the formation of some cavities with variable sizes in the area of the enamel irradiated with the $\mathrm{CO}_{2}$ laser, clearly showing fissures as had Ferreira et al. (1989).

Besides the cavities, Miserindo et al. (1989) also revealed the presence of major deep destruction when the energy parameters were increased. Cavities with smooth and vitrified walls were observed by Takahashi et al. when the number of pulses was increased. In our data we confirmed the presence of smooth walls between the rugosities. This is probably due to the use of different energy density and power applied in the different experiments. Other authors, such as Lobene et al. (1968), on the contrary, state that there was no formation of cavities when they irradiated the teeth fissures with the $\mathrm{CO}_{2}$ laser. They further identified the melted and whitish aspect of the surfaces.

With regard to the surface of the human deciduous teeth dentin irradiated with the $\mathrm{CO}_{2}$ laser, our findings revealed the presence of a fairly circular and well-delimited area, containing dentin blocks between fissures and cracks. These characteristics were also noticed by Watanabe et al. (1997) in permanent human teeth, identifying the presence of small holes in the interior of the dentin blocks, whereas Lan et al. (2000) observed the presence of fissures and cracks on the dentinary surface irradiated with smear layer. On the dentinary surface irradiated without the presence of smear layer, there was a flat cavity with melted masses. The margin was irregular and well defined.

The use of the Nd:YAG laser in this work revealed melting and resolidification of the enamel surface of the deciduous human teeth irradiated, based on the three-dimensional images by the scanning electron microscope, agreeing with the findings of Rode et al. According to some authors (Shirazuka et al., 1991; Pelino et al., 1999), the morphological alterations on the irradiated enamel surfaces make it more resistant with regard to demineralization. Laser irradiation associated to the fluor, is also efficient in the increase of the enamel resistance (Twasi et al., 1991), and in the increase of the fluor incorporation (Tagomori \& Morioka, 1989), being able to play an important role in the prevention or removal of dental caries (White et al.).

In our results, we noticed the typical melting appearance of the irradiated enamel surface, forming enamel 

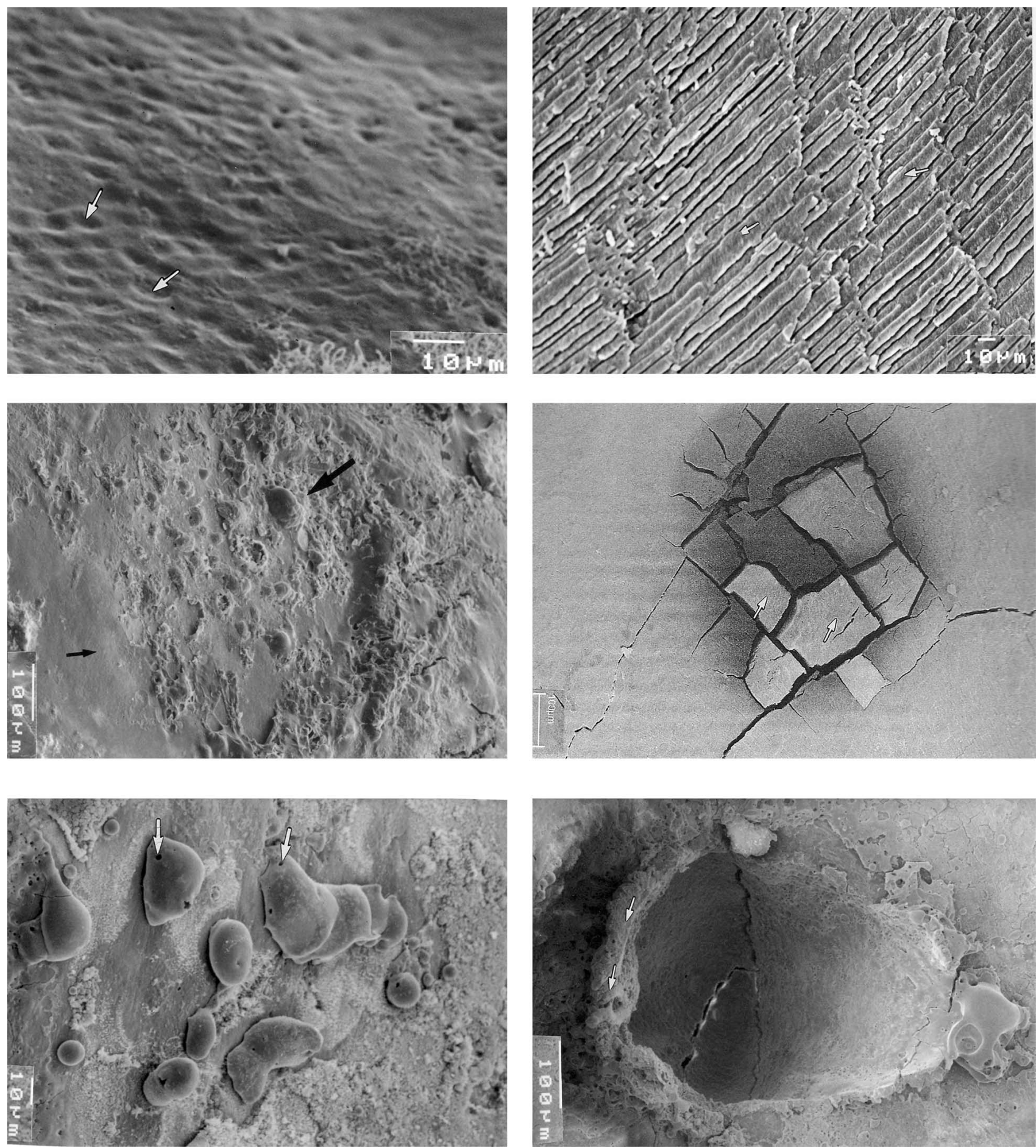

Fig. 1. SEM image of normal enamel surface of deciduos teeth showing the enamelm prism (arrow). Bar $10 \mu \mathrm{m}$.

Fig. 2. SEM image of normal dentin surface showing numerous parallel dentinary tubules. Bar $10 \mu \mathrm{m}$.

Fig. 3. SEM image of enamel surface irradiated with $\mathrm{CO}_{2}$ laser showing irregular areas with rugosites (large arrow) and smooth enamel surface (small arrow). Bar $100 \mu \mathrm{m}$.

Fig. 4. Surface of dentin irradiated with $\mathrm{CO}_{2}$. Shows blocks of fractured dentin (arrows) and fissures. Bar 100 $\mu \mathrm{m}$.

Fig. 5. Surface of enamel irradiated with Nd:YAG laser. Shows the «melting» with the presence of enamel granules and holes (arrows). Bar $10 \mu \mathrm{m}$.

Fig. 6. Surface of dentine irradiated with Nd:YAG laser revealing a very deep and delimited cavity with elevated margins. Bar $100 \mu \mathrm{m}$. 

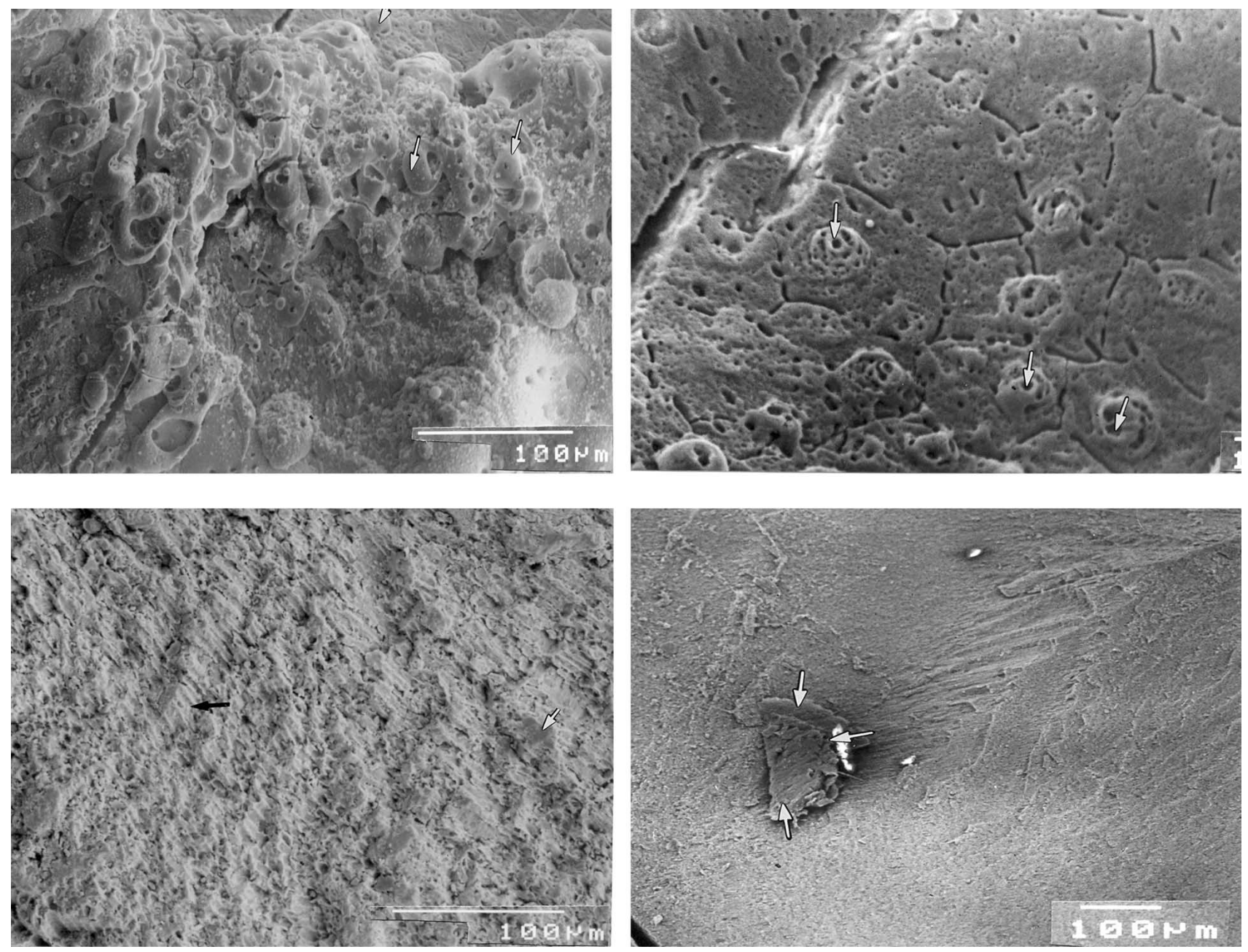

Fig. 7. Surface dentine irradiated with Nd:YAG laser. Note the presence of granules nad holes in the cavity margin with the melting of dentine surface (arrows). Bar $10 \mu \mathrm{m}$.

Fig. 8. The botton of the cavity irrdiated with Nd:YAG laser, showing dentinary tubules, melted dentin globules and holes (arrows). Bar $10 \mu \mathrm{m}$.

Fig. 9. Surface of enamel irradiated with diode laser shows the aspect of fusion in some areas (white arrow) and enamel prisms (black arrow). Bar $100 \mu \mathrm{m}$.

Fig. 10. Surface of dentin irradiated with diode laser shows the delimitation block of relatively smooth melted dentin (arrow). Bar $100 \mu \mathrm{m}$.

granules of variable sizes, with small shallow cavities around some of them, in agreement with the findings of Myaki et al. (1998) and Hess (1990). Furthermore, RauhamaaMäkinen et al. (1991) did not notice the presence of cavities when only the Nd:YAG laser was irradiated on the surface of the enamel and the dentin of the extracted teeth.

The dentin surface irradiated with the Nd:YAG laser in the deciduous teeth, our findings revealed the formation of well-delimited cavities with elevated margins containing granules of melted dentin and holes, in agreement with the findings of Watanabe et al. (1997), who defined the irradiated area as circular or elongated. The presence of these cavities was also observed by Lan et al. Furthermore, in the interior of the cavity, there were globules of melted dentin, clearly showing holes and formation of some cracks. Lin et al. also noticed the existence of globules, not only in the interior, but also outside the cavity with the increase of the pulse, forming a deeper cavity and with cracks. Myaki et al. clearly revealed the morphological aspect of melting and vitrification of the dentin surface of the deciduous human teeth.

There are hardly any studies with regard to the effects of the diode laser in the dental structures. The literature consulted did not show any work commenting its effects on the dentin surface, but only on the enamel surface. Our results revealed that the enamel surface of the deciduous teeth suffered melting and resolidification, agreeing with the 
findings of Wetter, who observed the effects of the diode laser with the scanning electron microscope. These alterations suggest a resistance increase of the dental enamel versus the acids, thus possibly playing an important role in the prevention of dental caries.

We can conclude that the three types of lasers induced different aspects of morphological alteration, both on the enamel and the dentin surfaces of all the deciduous teeth irradiated. These evident alterations on the surface of the enamel and the dentin of the deciduous teeth irradiated with the $\mathrm{CO}_{2}, \mathrm{Nd}$ :YAG and diode lasers, in the future can suggest extrapolation for certain dental clinical procedures.

\section{ACKNOWLEGEMENTS}

The authors express immense thanks to Mr. Sebastião Boleta and Mr.Gerson Batista (in memorian) for their technical assistance, and to the LELO-USP (Special Laboratory of Laser in Odontology in University of São Paulo).

SOUZA, M. R.; WATANABE, I.; AZEVEDO, L. H. \& TANJI, E. Y. Alteraciones morfológicas de las superficies de esmalte y dentina de dientes deciduos irradiados con lasers de Nd:YAG, $\mathrm{CO}_{2}$ y diodo. IInt. J. Morphol., 27(2):441-446, 2009.

RESUMEN: El estudio presenta algunos resultados del efecto del láser de $\mathrm{CO}_{2}, \mathrm{Nd}$ :YAG y Diodo sobre el esmalte y dentina de dientes deciduos humanos. Después de las irradiaciones, se prepararon las muestras y se montaron sobre bases metálicas, cubiertas con oro y examinadas en el microscopio electrónico de barrido. Los resultados mostraron que la irradiación con el láser $\mathrm{CO}_{2}$ en modo conmutado con 1,0 W de potencia, provoca fusión e irregularidades con pequeños cráteres en la superficie del esmalte. En la superficie de la dentina, el área irradiada se mostró circular y bien definido, con bloques de dentina y grietas. Con el uso del láser Nd: YAG en el modo pulsado con $1,0 \mathrm{~W}$ de potencia media y frecuencia de $10 \mathrm{~Hz}$, la superficie del esmalte presentó gránulos de esmalte fundido, dándole el aspecto de "melting" (derretido). La superficie de dentina irradiada presentó un cráter con borde elevado con gránulos y agujeros, y su fondo presentó túbulos dentinarios con glóbulos de dentina derretida. La irradiación del láser de Diodo en el modo conmutado con potencia media de $1,0 \mathrm{~W}$, provocó la formación de una superficie de esmalte fusionada y resolidificada uniforme y la superficie de la dentina presentó un bloque de dentina fundida en la regiones adyacentes de dentina normal, mostrando una superficie bastante lisa.

PALABRAS CLAVE: Diente decíduo; Esmalte; Dentina; Láser CO2; Láser Nd:YAG; Láser diodo; Microscopia electrónica de barrido.

\section{REFERENCES}

Chomette, G.; Auriol, M.; Zeitoun, R. \& Mousques, T. Effect du soft-laser sur le tissu conjunctif gengival. II. Effect sur la cicatrisation Estude en microscopic optique, histoenzymologie et microscopie eletronique. J. Biol. Buccale, 15:51-7, 1987.

Ferreira, J. M.; Palamara, J.; Phakey, P. P.; Rachinger, W. A. \& Orams, H. J. Effects of continuous-wave $\mathrm{CO}_{2}$ laser on the ultrastructure of human dental enamel. Arch. Oral Biol., 34(7):551-62, 1989.

Hess, J. A. Scanning electron microscopic study of laser induced morphologic changes of a coated enamel surface. Laser Surg. Med., 10(5):458-62, 1990.

Kantorowitz, Z.; Featherstone, J. D. B. \& Fried, D. Argumentation of $\mathrm{CO}_{2}$ laser inhibition of in vitro caries by fluoride. J. Dent. Res., 75(1):25, 1996.

Lan, W. H.; Chen, K. W.; Jeng, J. H.; Lin, C. P. \& Lin, S. K. A comparison of the Morphological changes after Nd-
YAG and $\mathrm{CO}_{2}$ Laser irradiation of Dentin Surfaces. $J$. Endod., 26(8):450-3, 2000.

Lin, C. P.; Lee, B. S.; Lin, F. H.; Kok, S. H. \& Lan, W. H. Phase, Compositional, and Morphological changes of human dentin after Nd:YAG laser treatment. J. Endod., 27(6):389-93, 2001.

Lobene, R. R.; Brussry, B. R. \& Fine, S. Interaction of carbon dioxide laser radiation with enamel and dentin. J. Dent. Res., 47(2):311-7, 1968.

McCormack, S. M.; Fried, D.; Featherstone, J. D. B.; Glena, R. E. \& Seka, W. Scanning electron microscope observations of $\mathrm{CO}_{2}$ laser effects on dental enamel. $J$. Dent. Res., 74(10):1702-8, 1995.

Miserindo, L. J.; Neiburger, E. J.; Walia, H.; Luebke, N. \& Brantley, W. Thermal effects of continuous wave $\mathrm{CO}_{2}$ laser exposure on human teeth: an in vitro study. $J$. Endod., 15(7):302-5, 1989. 
Myaki, S. I.; Watanabe, I.; Eduardo, C. P. \& Issao, M. $\mathrm{Nd}$ :YAG laser effects on the oclusal surface of pre molar. Am. J. Dent., 11(3):103-5, 1998.

Pelino, J. E. P.; Mello, J. B. \& Eduardo, C. P. In vitro study of the Nd:YAG laser effect on human dental enamel: optical and electron microscope analysis. J. Clin. Laser Med. Surg., 17(4):171-7, 1999.

Rauhamaa-Mäkinen, R.; Meurman, J. H.; Luomanen, M.; Torkko, H.; Viherkoski, E. \& Paunio, I. Irradiation of human dental tissues with $\mathrm{CO}_{2}^{-}, \mathrm{Nd}$ :YAG-, and $\mathrm{CO} 2-$ Nd:YAG combination laser. Scand. J. Dent. Res., 99(6):470-5, 1991.

Rode, S. M.; Andrade, C. S.; Eduardo, C. P. \& Ando, T. Ação do laser Nd-YAG sobre o esmalte de dentes decíduos humanos. Estudo ultraestrutural in vitro. Anais da reunião científica da Sbpqo, 10:8, 1994.

Shirazuka, T.; Kodaka, K.; Debari, K. \& Matsumoto, K. Acid resistance on human dental enamel by laser irradiation and fluoride treatment. J. Dent. Res., 70:350, 1991,

Stern, R. H.; Sognnaes, R. F. \& Goodman, F. Laser effect on "in vitro" enamel permeability and solubility. J. Am. Dent. Assoc., 73:836-43, 1966.

Stern, R. H.; Vahl, J.; Sognnaes, R. F. Laser enamel: ultrastructure observations of pulsed carbon dioxide laser effects. J. Dent. Res., 55:455-60, 1972.

Tagomori, S. \& Morioka, T. Combined effects of laser and fluoride on acid resistance of human dental enamel. $\mathrm{Ca}$ ries Res., 23(4):223-31, 1989.

Takahashi, K.; Kimura, Y. \& Matsumoto, K. Morphological and atomic analytical changes after $\mathrm{CO}_{2}$ laser irradiation emitted at $9.3 \mathrm{~mm}$ on human dental hard tissues. J. Clin. Laser Med. Surg., 16(3):167-73, 1998.

Taylor, R.; Shklar, G. \& Roeber, F. The effects of laser radiation on teeth dental pulp, and oral mucosa of experimental animals. Oral Surg., 19:786-95, 1965.

Twasi, T.; Tagomori, S.; Bahar, A. \& Morioka, T. Effect of Nd:YAG laser on tips and fissures of enamel. J. Dent. Res., 71(4):1039, 1991.

Watanabe, I.; Liberti, E. A.; Azeredo, R. A.; Araújo, M. V.; Sobrinho, A. N. \& Goldenberg, S. The effects of $\mathrm{CO}_{2}$ laser irradiation human permanent molar. A scanning electron microscopic study. Estomat. Cult., 16:27-30, 1986.

Watanabe, I.; Matsumoto, K.; Katayama, A. Y.; Brugnera, A. \& Lopes, M. C. Efeitos da luz "laser"CO e Nd:YAG sobre a superfície dentinária: estudo ao microscópio eletrônico de varredura. Rev. Bras. Odontol., 54(3):167$70,1997$.

Watanabe, I.; Semprini, M.; Lopes, R. A. \& Morais, J. O. R. Efeitos da irradiação do raio laser $\mathrm{CO}_{2}$ no esmalte de dentes decíduos humanos: Estudo ao microscópio eletrônico de varredura. Rev. Bras. Odont., 47(4):22-7, 1990.

Wetter, N. U. Estudo das Alterações morfológicas do esmalte dentário irradiado com laser de diodo de alta potência: análise por microscopia eletrônica de varredura. Rev. Bras. Pesq. Desenv., 4(1):14-9, 2002.

White, J. M.; Goodis, H. E.; Setcos, J. C.; Eakle, S. W.; Hulscher, B. E. \& Rose, C. L. Effects of pulsed Nd:YAG laser energy on human teeth: a three-year follow-up study. J. Am. Dent. Assoc., 124:45-51, 1993.

Yamada, K. Caries prevention by laser irradiation to dental enamel. International Congress on Lasers in dentistry, 5:131-7, 1996.

Correspondence to:

Dra. Mônica Rodrigues de Souza

Universidade de São Paulo

São Paulo, S.P.

BRASIL

Email: Prof. Dr. li-Sei Watanabe watanabe@icb.usp.br

Received: 27-07-2008

Accepted: 22-01-2009 